\title{
Penerapan Metode Giving Question and Getting Answer untuk Meningkatkan Hasil Belajar Peserta Didik pada Mata Pelajaran Pendidikan Agama Islam
}

\author{
Hesti Yulianti \\ Institut Agama Islam Darussalam (IAID) Ciamis \\ Email: hesti_yulianti94@yahoo.co.id \\ Cecep Darul Iwan \\ Institut Agama Islam Darussalam (IAID) Ciamis \\ Email: cecep.daruliwan@gmail.com \\ Saeful Millah \\ Institut Agama Islam Darussalam (IAID) Ciamis \\ Email: saeful.millahcms@gmail.com \\ Received: February 1, 2018 | Accepted: September 17, 2018
}

\begin{abstract}
This class action research aims to improve the quality of student learning outcomes in Islamic Religious Education subjects. The alternative offered to achieve that goal is to introduce the giving question and getting answer method. This study uses the Classroom Action Research (CAR) method of Kurt Lewin's model. Data collection techniques used were observation and tests. Classroom Action Research in class VIII H, SMP Negeri 1 Baregbeg, Ciamis Regency. The steps of data analysis are as follows: data selection, data correction and data weighting. The results of this study prove that the giving question and getting answer method has succeeded in improving the quality of student learning outcomes in Islamic Religious Education subjects at the Baregbeg State Middle School in Ciamis Regency.
\end{abstract}

\begin{abstract}
Abstrak
Penelitian tindakan kelas ini bertujuan untuk meningkatkan mutu hasil belajar siswa pada mata pelajaran Pendidikan Agama Islam. Alternatif yang ditawarkan untuk mencapai tujuan itu adalah dengan memperkenalkan metode giving question and getting answer. Penelitian ini menggunakan metode Penelitian Tindakan Kelas (PTK) model Kurt Lewin. Teknik pengumpulan data yang digunakan adalah observasi dan tes. Penelitian Tindakan Kelas di kelas VIII H SMP Negeri 1 Baregbeg Kabupaten Ciamis. Langkah-langkah analisis data sebagai berikut: seleksi data, pengoreksian data dan pembobotan data. Hasil penelitian ini membuktikan bahwa metode giving question and getting answer berhasil meningkatkan mutu
\end{abstract}


hasil belajar siswa pada mata pelajaran Pendidikan Agama Islam di Sekolah Menengah Pertama Negeri Baregbeg Kabupaten Ciamis.

\section{Keywords}

Islamic education curriculum, student outcomes, learning quality

\section{Pendahuluan}

Pendidikan pada dasarnya merupakan salah satu upaya yang sangat mendasar dalam pengembangan sumber daya manusia. Dalam konteks pendidikan di Indonesia, pendidikan diharapkan melahirkan sumber daya manusia yang unggul. Pendidikan hendaknya menumbuhkan dan mengembangkan kemampuan intelektual, sosial dan personal. Tiga kemampuan ini dibangun bukan hanya berlandaskan rasio dan logika saja, tetapi melibatkan aspek lain, yaitu inspirasi, kreativitas, moral, intuisi dan spiritual (Suprijono, 2012, p. 6).

Bila ditelusuri secara mendalam, proses belajar-mengajar merupakan inti dari proses pendidikan karena di dalamnya terjadi interaksi antara berbagai komponen pengajaran. Sebagaimana dikemukakan (Ali, 2002, p. 4), komponen-komponen itu dikelompokkan kedalam tiga kategori utama, yaitu: guru, isi atau materi pelajaran, dan peserta didik. Interaksi antara ketiga komponen utama tersebut melibatkan sarana dan prasarana, seperti metode, media, dan penataan tempat lingkungan belajar sehingga tercipta situasi proses belajar-mengajar yang memungkinkan tercapainya tujuan yang telah direncanakan sebelumnya.

Berbicara mengenai proses pembelajaran, tidak lepas dari fungsi dan peranan seorang guru. Peran guru sangat vital dalam menentukan output pendidikan. Dalam suatu kegiatan pembelajaran, guru hendaknya lebih memberdayakan peserta didik dalam kegiatan tersebut. Karena itulah guru harus mendesain pembelajaran sedemikian rupa sehingga bisa terjadi pembelajaran yang demokratis, berkarakter dan menyenangkan.

Pendidikan Agama Islam (PAI) merupakan salah satu mata pelajaran yang sangat penting untuk menyiapkan peserta didik dalam hal memahami, menghayati, dan mengimani hingga mengamalkan ajaran Islam melalui kegiatan bimbingan, pengajaran, dan latihan. Hal ini senada dengan apa yang dikemukakan oleh (Majid \& Andayani, 2004, p. 130), "PAI adalah usaha sadar bimbingan dan asuhan terhadap anak didik agar dapat memahami apa yang terkandung dalam Islam secara keseluruhan, menghayati makna dan maksud serta tujuannya, dan dapat mengamalkannya”. PAI adalah suatu usaha untuk 
membina dan mengasuh peserta didik agar senantiasa dapat memahami ajaran agama Islam secara menyeluruh. Lalu peserta didik menghayati tujuan yang pada akhirnya dapat mengamalkan serta menjadikan Islam sebagai pandangan hidup (Daradjat, 1996, p. 86).

Menurut Propenas 2000-2004 (UU No. 25 Tahun 2000) menyatakan bahwa PAI di sekolah umum (TK, SD, SMP, SMA) bertujuan untuk meningkatkan keimanan melalui pemberian dan pemupukan pengetahuan, penghayatan serta pengalaman peserta didik tentang agama Islam sehingga menjadi manusia muslim yang terus berkembang dalam hal keimanan, ketaqwaan serta pembinaan akhlak manusia dan budi pekerti luhur (Azizi, 2003, p. 75).

PAI yakni upaya mendidikkan agama Islam atau ajaran Islam dan nilainilainya agar menjadi way of life (pandangan dan sikap hidup) seseorang. Pengertian ini dapat berwujud : (1) segenap kegiatan yang dilakukan seseorang untuk membantu seorang atau sekelompok peserta didik dalam menanamkan atau menumbuhkembangkan ajaran Islam dan nilai-nilainya untuk dijadikan sebagai pandangan hidupnya, yang diwujudkan dalam sikap hidup dan dikembangkan dalam keterampilan hidupnya sehari-hari; (2) segenap fenomena atau peristiwa perjumpaan antara dua orang atau lebih yang dampaknya ialah tertanamnya atau tumbuhkembangnya ajaran Islam dan nilainilainya pada salah satu atau beberapa pihak (Muhaimin, 2006, p. 5:6).

Dari beberapa pengertian di atas, dapat disimpulkan bahwa PAI adalah suatu usaha untuk membina dan mengasuh peserta didik agar senantiasa dapat memahami ajaran agama Islam secara menyeluruh.

Menurut Arif (2008, p. 45), tujuan adalah suatu yang diharapkan tercapai setelah sesuatu usaha atau kegiatan selesai. Tujuan pendidikan merupakan masalah inti dalam pendidikan dan sari pati dari seluruh renungan pedagogik. Dengan demikian tujuan pendidikan merupakan faktor yang sangat menentukan jalannya pendidikan sehingga perlu dirumuskan sebaik-baiknya sebelum semua kegiatan pendidikan dilaksanakan.

Kurdi (2006, p. 13) merumuskan bahwa tujuan dasar PAI adalah dalam rangka membekali kepribadian peserta didik ke arah yang lebih baik, agar secara spiritual telah bersemayam dalam dirinya dan secara psikologis serta sosial mampu beradaptasi dengan lingkungan. Menurut Hamdani dalam (Zulkarnain, 2008, p. 19), tujuan PAI yaitu sebagai pengabdian diri manusia kepada pencipta alam dengan tidak melupakan kehidupan dunia.

Adapun Omar Muhammad Attoumy Asy-Syaebani tujuan PAI ada 4 ciri pokok: 1) Sifat dan corak agama dan akhlak; 2) Sifat keseluruhan yang mencakup segala aspek pribadi peserta didik dan semua aspek perkembangan masyarakat; 3) Sifat keseimbangan, keselarasan, tidak adanya pertentangan 
antara unsur-unsur dan cara pelaksanaannya; 4) Sifat realistik dan dapat dilaksanakan, penekanan pada perubahan yang dikehendaki pada tingkah laku dan pada kehidupan(Achmadi, 2005, p. 91).

Tujuan umum PAI lebih bersifat empirik dan realistik. Tujuan umum berfungsi sebagai arah yang taraf pencapaiannya dapat diukur karena menyangkut perubahan sikap, perilaku dan kepribadian peserta didik sehingga mampu menghadirkan dirinya sebagai sebuah pribadi yang utuh (Achmadi, 2005, p. 91).

Untuk mencapai tujuan umum tersebut tidak akan dapat dicapai sekaligus, akan tetapi membutuhkan proses dan waktu yang panjang dengan tahap-tahap tertentu, sedangkan tiap tahap yang dilalui juga mempunyai tujuan tertentu yang disebut dengan tujuan khusus. Adapun tujuan khusus PAI bersifat relatif sehingga memungkinkan untuk diadakannya perubahan dimana sesuai dengan tuntutan dan kebutuhan. Adapun tujuan PAI tersebut adalah sebagai berikut: 1) Peserta didik bergairah beribadah; 2) Peserta didik mampu membaca Al-Qur'an; 3) Penanaman rasa agama pada peserta didik; 4) Menanamkan rasa cinta pada Allah dan Rasul-Nya; 5) Memperkenalkan ajaran Islam yang bersifat global seperti rukun Islam, rukun iman dan lain-lain merupakan materi pokok; 6) Membiasakan peserta didik berakhlak mulia, melatih peserta didik untuk mempraktikan ibadah yang praktis dan membiasakan contoh teladan yang baik (Zuhairini, 1993, p. 36). Jadi tujuan pembelajaran PAI adalah untuk membentuk peserta didik yang beriman dan bertaqwa kepada Allah serta memiliki pengetahuan yang luas tentang Islam dan berakhlakul karimah.

Majid \& Andayani (2004, p. 134:135) menyebutkan kurikulum PAI untuk sekolah atau madrasah berfungsi sebagai berikut: 1) Pengembangan, yaitu meningkatkan keimanan dan ketaqwaan peserta didik kepada Allah SWT yang telah ditanamkan dalam lingkungan keluarga. Pada dasarnya kewajiban menanamkan keimanan dan ketaqwaan dilakukan oleh setiap orang tua dalam keluarga. Sekolah berfungsi untuk menumbuh kembangkan lebih lanjut dalam diri anak melalui bimbingan, pengajaran dan pelatihan agar keimanan dan ketaqwaan tersebut dapat berkembang secara optimal sesuai dengan tingkat perkembangannya; 2) Penanaman nilai, sebagai pedoman hidup untuk mencari kebahagiaan hidup di dunia dan di akhirat; 3) Penyesuaian mental, yaitu untuk menyesuaikan diri dengan lingkungan baik lingkungan fisik maupun lingkungan sosial dan dapat mengubah lingkungannya sesuai dengan ajaran agama Islam; 4) Perbaikan, yaitu memperbaiki kesalahan-kesalahan, kekurangan-kekurangan dan kelemahan-kelemahan peserta didik dalam keyakinan, pemahaman dan pengalaman ajaran Islam dalam kehidupan seharihari; 5) Pencegahan, yaitu untuk menangkal hal-hal negatif dari lingkungannya 
atau dari budaya lain yang dapat membahayakan dirinya dan menghambat perkembangannya; 6) Pengajaran, tentang ilmu pengetahuan keagamaan secara umum (alam nyata dan tidak nyata), sistem dan fungsionalnya; 7) Penyaluran, yaitu untuk menyalurkan peserta didik yang memiliki bakat khusus di bidang agama Islam agar bakat tersebut dapat berkembang secara optimal sehingga dapat dimanfaatkan untuk dirinya sendiri dan bagi orang lain. Jadi, fungsi pembelajaran PAI untuk sekolah atau madrasah adalah sebagai pengembangan, penanaman nilai, penyesuaian mental, perbaikan, pencegahan, pengajaran dan penyaluran.

Ruang lingkup pendidikan Islam tidak mengenal batas umur dan perbedaan jenis kelamin bahkan tempat dan masa. Pendidikan sebagai ilmu, mempunyai ruang lingkup yang sangat luas karena di dalamnya banyak segisegi atau pihak-pihak yang ikut terlibat baik langsung maupun tidak langsung (Nafis, 2011, p. 26:30). Adapun segi-segi dan pihak-pihak yang terlibat dalam pendidikan Islam sekaligus menjadi ruang lingkup pendidikan Islam adalah: 1) Perbuatan mendidik itu sendiri. Maksud dari perbuatan mendidik di sini adalah seluruh kegiatan, tindakan atau perbuatan dan sikap yang dilakukan oleh pendidikan sewaktu menghadapi atau mengasuh peserta didik. Dalam perbuatan mendidik ini sering disebut dengan istilah tahzib; 2) Dasar dan tujuan pendidikan Islam. Landasan yang menjadi fundamen serta sumber dari segala kegiatan pendidikan Islam. Semua hal yang masuk dalam proses pendidikan harus bersumber dan berlandaskan dasar tersebut. Dengan dasar dan sumber ini, peserta didik akan dibawa dengan sesuai dasar dan sumbernya; 3) Peserta didik. Pihak yang merupakan obyek terpenting dalam pendidikan. Hal ini disebabkan karena segala tindakan pendidikan diarahkan pada tujuan dan cita-cita pendidikan Islam. 4) Pendidik. Secara singkat dapat dikatakan sebagai subyek pelaksana proses pendidikan. Pendidik akan dapat membawa suatu pendidikan pada baik dan buruknya, sehingga peranan pendidik dalam keberhasilan pendidikan sangat menentukan; 5) Materi dan kurikulum pendidikan Islam. Bahan-bahan atau pengalaman-pengalaman pendidikan, yang sudah tersusun secara sistematis dan terstruktur untuk disampaikan dalam proses pendidikan kepada peserta didik; 6) Metode pendidikan Islam. Cara dan pendekatan yang dirasa paling tepat dan sesuai dalam pendidikan untuk menyampaikan bahan dan materi pendidikan kepada peserta didik. Metode ini digunakan untuk mengolah, menyusun, dan menyajikan materi pendidikan, supaya materi dapat dengan mudah diterima peserta didik sesuai dengan karakteristik dan tahapan peserta didik; 7) Evaluasi pendidikan Islam. Caracara yang digunakan untuk menilai hasil pendidikan yang sudah dilakukan. Pada pendidikan Islam, umumnya tujuan tidak semuanya dapat dicapai seketika dan sekaligus, melainkan melalui proses tahapan tertentu; 8) Alat-alat 
pendidikan Islam. Alat-alat yang digunakan selama proses pendidikan dilaksanakan, agar tujuan pendidikan dapat tercapai dengan tepat; 9) Lingkungan pendidikan Islam. Keadaan-keadaan dan tempat-tempat yang ikut berpengaruh dalam pelaksanaan serta keberhasilan suatu pendidikan (Nafis, 2011, p. 26:30).

Pelajaran PAI yang dipelajari di sekolah berperan sangat penting dalam memberikan pemahaman terhadap peserta didik, sehingga setelah mereka mengetahui dan memahami materi yang diberikan diharapkan mereka mampu menerapkannya dalam kehidupan nyata. Mengingat pentingnya peranan pendidikan Islam dalam kehidupan nyata, maka sekolah perlu meningkatkan berbagai usaha untuk meningkatkan hasil belajar peserta didik.

Menurut Suprijono (2009, p. 5), bentuk hasil belajar dapat berbentuk pola-pola perbuatan, internalisasi nilai-nilai, pemahaman terhadap pengertianpengertian, terbentuknya sikap-sikap, apresiasi dan keterampilan. Dengan demikian, hasil belajar adalah perubahan perilaku secara komprehensif, meliputi seluruh aspek kemanusiaan. Hasil belajar tersebut tidak dilihat secara terpisah-pisah, tetapi terintegrasi secara menyeluruh.

Hasil belajar tidak dapat dipisahkan dari perbuatan belajar, karena belajar merupakan suatu proses. Bagi peserta didik, belajar merupakan suatu kewajiban, adapun berhasil tidaknya sangat dipengaruhi oleh banyak faktor. Belajar pada manusia adalah interaksi aktif dengan lingkungan yang disertai dengan aktivitas mental yang menimbulkan perubahan-perubahan dalam aspek kognitif, afektif dan psikomotor. (Winkel, 1996, p. 193).

Adapun pengertian hasil belajar yang dikemukakan oleh beberapa ahli, di antaranya: 1) hasil belajar adalah hasil penilaian pendidikan tentang kemajuan setelah melakukan aktivitas belajar atau merupakan akibat dari kegiatan belajar (Djamarah \& Zain, 2006, p. 119); 2) hasil belajar adalah tujuan akhir dilaksanakannya kegiatan pembelajaran di sekolah (Dimayati \& Mudjiono, 2006, p. 3): 3) Indikator bahwa seseorang telah berhasil belajar adalah tampaknya perubahan perilaku dalam dirinya (Wahidmurni, 2010, p. 18); 4) hasil belajar adalah hasil belajar adalah kompetensi-kompetensi yang dimiliki siswa setelah melakukan interaksi dengan lingkungan belajaranya (Sudjana, 2010, p. 22); 5) hasil belajar adalah pola-pola perbuatan, nilai-nilai, pengertian-pengertian, sikap-sikap, apresiasi dan keterampilan (Suprijono, 2009, p. 5).

Gagne (Suprijono, 2009, p. 5:6) mengemukakan bahwa hasil belajar berupa: a) Informasi verbal yaitu kepasitas mengungkapkan dalam bentuk bahasa, baik lisan maupun tertulis; b) Keterampilan intelektual yaitu kemampuan mempresentasikan konsep dan lambang; c) Strategi kognitif yaitu kecakapan menyalurkan dan mengarahkan aktivitas kognitifnya sendiri; d) 
Keterampilan motorik yaitu kemampuan melakukan serangkaian gerak jasmani; e) Sikap yaitu kemampuan menerima atau menolak objek berdasarkan penilaian terhadap objek tersebut.

Sopiatin \& Sahroni (2011, p. 67:68) mengemukakan bahwa hasil belajar dalam rangka studi dicapai melalui tiga kategori ranah antara lain kognitif, afektif dan psikomotorik. Menurut Hamalik (2008, p. 66:70), kegiatan belajar mengajar di dalamnya seperti mengorganisasi pengalaman belajar, menilai proses dan hasil belajar, termasuk dalam cakupan tanggung jawab guru dalam pencapaian hasil belajar peserta didik. Berdasarkan teori Taksonomi Bloom, hasil belajar dalam rangka studi dicapai melalui tiga kategori ranah, antara lain kognitif, afektif dan psikomotorik. Adapun perinciannya adalah sebagai berikut:

Pertama, ranah kognitif. Ranah ini berkenaan dengan hasil belajar intelektual yang terdiri dari 6 aspek yaitu: 1) Pengetahuan (Knowledge). Pengetahuan adalah aspek yang paling dasar dalam taksonomi Bloom, seringkali disebut juga aspek ingatan (recall). Dalam jenjang ini kemampuan seseorang dituntut untuk dapat mengenali atau mengetahui adanya konsep, fakta atau istilah-istilah dan lain sebagainya tanpa harus mengerti atau dapat menggunakannya (Daryanto, 2007, p. 103); 2) Pemahaman (Comprehension). Kemampuan ini umumnya mendapat penekanan dalam proses belajarmengajar. Peserta didik dituntut memahami atau mengerti apa yang diajarkan, mengetahui apa yang sedang dikomunikasikan dan dapat memanfaatkan isinya tanpa keharusan menghubungkannya dengan hal-hal lain. Bentuk soal yang sering digunakan untuk mengukur kemampuan ini adalah pilihan ganda dan uraian (Daryanto, 2007, p. 106); 3) Penerapan (Application). Jenjang kemampuan ini dituntut kesanggupan ide-ide umum, tata cara ataupun metode-metode, prinsip-prinsip serta teori-teori dalam situasi baru dan konkret. Pengukuran kemampuan ini umumnya menggunakan pendekatan pemecahan masalah. Melalui pendekatan ini peserta didik dihadapkan dengan suatu masalah yang perlu dipecahkan dengan menggunakan pengetahuan yang dimilikinya. Bentuk soal yang sesuai untuk mengukur aspek penerapan antara lain pilihan ganda dan uraian (Daryanto, 2007, p. 109). 3) Analisis (Analysis). Jenjang kemampuan ini seseorang dituntut untuk dapat menguraikan suatu situasi atau keadaan tertentu ke dalam unsur-unsur atau komponen-komponen pembentuknya. Dengan jalan ini situasi atau keadaan tersebut menjadi lebih jelas. Bentuk soal yang sesuai untuk mengukur kemampuan ini adalah pilihan ganda dan uraian. Kemampuan analisis diklasifikasi atas tiga kelompok, yaitu analisis unsur, analisis hubungan dan analisis prinsip-prinsip yang terorganisasi (Daryanto, 2007, p. 110:111); 4) Sintesis (Synthesis). Sintesis adalah kemampuan merangkum berbagai komponen atau unsur sehingga menjadi 
sesuatu yang baru. Pada jenjang ini seseorang dituntut untuk dapat menghasilkan sesuatu yang baru dengan jalan menggabungkan berbagai faktor yang ada. Hasil yang diperoleh dari penggabungan ini dapat berupa tulisan dan rencana atau mekanisme(Daryanto, 2007, p. 112); 5) Penilaian (evaluation). Jenjang kemampuan ini seseorang dituntut untuk dapat mengevaluasi situasi, keadaan, pernyataan atau konsep berdasarkan suatu kriteria tertentu. Yang penting dalam evaluasi ialah menciptakan kondisinya sedemikian rupa sehingga peserta didik mampu mengembangkan kriteria, standar atau ukuran untuk mengevaluasi sesuatu. (Daryanto, 2007, p. 113).

Kedua Ranah afektif. Ranah ini berkenaan dengan sikap dan nilai serta meliputi lima jenjang kemampuan, yaitu: 1) Menerima (Receiving). Menerima diartikan sebagai kesediaan peserta didik untuk memperhatikan fenomena atau stimulus tertentu. Yakni semacam kepekaan dalam menerima rangsangan (stimulasi) dari luar yang datang kepada peserta didik dalam bentuk masalah, situasi, gejala dan lain-lain. Dalam sub-ranah ini dapat berupa kepedulian terhadap keberadaan suatu stimulus, keinginan untuk menerimanya dan memperhatikan secara selektif terhadap bagian dari stimulus tersebut (Abdullah, 2012, p. 31); 2) Menanggapi (Responding). Menanggapi diartikan sebagai adanya partisipasi aktif dalam diri peserta didik terhadap sesuatu. Pada tahap ini peserta didik tidak hanya memperhatikan terhadap fenomena tertentu, tetapi juga memberikan reaksi dengan cara tertentu. Hasil belajar dalam sub-ranah ini antara lain berupa kesediaan merespon sesuai dengan yang diintruksikan, kemauan melakukan lebih dari yang diminta dan adanya kepuasan dalam memberikan respon (Abdullah, 2012, p. 32); 3) Penilaian (Valuing). Penilaian berkenaan dengan nilai dan kepercayaan terhadap gejala atau stimulus. Dalam evaluasi ini termasuk di dalamnya kesediaan menerima nilai, latar belakang atau pengalaman untuk menerima nilai dan kesepakatan terhadap nilai tersebut. Hasil belajar dalam sub-ranah ini ditunjukkan dengan tingkah laku yang stabil dan konsisten sehingga nilai-nilai yang ada dibalik tingkah laku itu dapat diidentifikasi (Abdullah, 2012, p. 33); 4) Organisasi (Organization). Organisasi dapat dipahami sebagai usaha mempertemukan berbagai nilai yang berbeda dengan tanpa dikonflikkan, kemudian dikembangkan sistem nilai yang secara internal konsisten. Dengan demikian, penekananya dalam hal ini adalah membandingkan, menghubungkan dan mengambil sintesis dari berbagai nilai tersebut (Abdullah, 2012, p. 34); 5) Karakterisasi dengan suatu nilai atau kompleks nilai (Characterization by a value or value complex). Pada level ini, peserta didik telah mempunyai sistem nilai yang mengendalikan tingkah lakunya dalam waktu yang relatif lama untuk mengembangkan suatu gaya hidup (life style). Hasil belajar dalam subranah ini berupa berbagai aktivitas namun tekanannya adalah bahwa tingkah 
laku yang ditampilkan itu merupakan karakteristik dari peserta didik tersebut (Abdullah, 2012, p. 34).

Ketiga, Ranah psikomotorik. Meliputi keterampilan motorik, manipulasi benda-benda, koordinasi neuromuscular (menghubungkan, mengamati). 1) Keterampilan motorik (muscular or motor skills): memperlihatkan gerak, menunjukkan hasil (pekerjaan tangan), menggerakkan, menampilkan, melompat dan sebagainya; 2) Manipulasi benda-benda (manipulation of materials or objects): menyusun, membentuk, memindahkan, menggeser, mereparasi dan sebagainya; 3) Koordinasi neuromuscular, menghubungkan, mengamati, memotong dan sebagainya (Daryanto, 2007, p. 124).

Pencapaian ketiga ranah hasil belajar tersebut, sangat dipengaruhi oleh berbagai faktor. Secara umum faktor-faktor yang mempengaruhi hasil belajar dibedakan atas dua kategori, yaitu faktor internal dan faktor eksternal. Kedua faktor tersebut saling mempengaruhi dalam proses belajar individu sehingga menentukan kualitas hasil belajar (Baharudin \& Wahyuni, 2015, p. 22:23).

Faktor internal adalah faktor yang berasal dari dalam diri individu dan dapat mempengaruhi hasil belajar. Faktor ini meliputi faktor fisiologis dan psikologis. 1) Faktor fisiologis adalah faktor yang berhubungan dengan kondisi fisik individu. Faktor-faktor ini dibedakan menjadi dua macam, yaitu keadaan jasmani dan keadaan fungsi jasmani; 2) Faktor psikologis adalah keadaan psikologis seseorang yang dapat mempengaruhi proses belajar. Beberapa faktor psikologis yang mempengaruhi hasil belajar yaitu: a) Kecerdasan/intelegensi peserta didik. Kecerdasan sebagai kemampuan psiko-fisik dalam mereaksi rangsangan atau menyesuaikan diri dengan lingkungan melalui cara yang tepat. Semakin tinggi tingkat intelegensi seorang individu, semakin besar peluang individu tersebut meraih sukses dalam belajar; b) Motivasi. Motivasi adalah salah satu faktor yang mempengaruhi keefektifan kegiatan belajar peserta didik. Motivasi dapat mendorong peserta didik untuk melakukan kegiatan belajar; c) Minat. Secara sederhana, minat berarti kecenderungan dan kegairahan yang tinggi atau keinginan yang besar terhadap sesuatu; d) Sikap. Sikap adalah gejala internal yang berdimensi efektif berupa kecenderungan untuk meraksi atau merespon dengan cara yang relatif tetap terhadap objek. Sikap individu dapat mempengaruhi hasil belajarnya; e) Bakat. Bakat didefinisikan sebagai kemampuan potensial yang dimiliki seseorang untuk mencapai keberhasilan pada masa yang datang. Individu yang memiliki bakat tertentu akan lebih mudah menyerap segala informasi yang berhubungan dengan bakat yang dimilikinya.

Faktor eksternal adalah faktor-faktor yang ada di luar diri individu. Faktor-faktor internal yang mempengaruhi hasil belajar digolongkan menjadi dua, yaitu faktor lingkungan sosial dan faktor lingkungan non-sosial 
(Baharudin \& Wahyuni, 2015, p. 32). Lingkungan sosial meliputi: a) Lingkungan sosial sekolah seperti guru, administrasi dan teman-teman sekelas dapat mempengaruhi proses belajar seorang peserta didik; b) Lingkungan sosial masyarakat, kondisi lingkungan masyarakat, tempat tinggal peserta didik akan mempengaruhi belajar peserta didik; c) Lingkungan sosial keluarga, lingkungan ini sangat mempengaruhi kegiatan belajar. Ketegangan keluarga, sifat-sifat orang tua, demografi keluarga (letak rumah), pengelolaan keluarga, semuanya dapat memberi dampak terhadap aktivitas belajar peserta didik.

Adapun Lingkungan non-sosial meliputi: a) Lingkungan alamiah, seperti lokasi udara yang segar, tidak panas dan tidak dingin, sinar yang tidak terlalu silau atau tidak terlalu gelap dan suasana yang sejuk dan tenang. Apabila kondisi tidak mendukung, maka proses belajar peserta didik akan terhambat; b) Faktor instrumental, yaitu perangkat belajar yang dapat digolongkan menjadi dua macam. Pertama, hardware seperti gedung sekolah, alat-alat belajar, fasilitas belajar, lapang olahraga dan sebagainya. Kedua, software seperti kurikulum sekolah, peraturan sekolah, buku panduan, silabus, dan lain sebagainya; c) Faktor materi pelajaran (yang diajarkan kepada peserta didik). Faktor ini hendaknya disesuaikan dengan perkembangan peserta didik, begitu juga dengan strategi mengajar guru hendaknya disesuaikan dengan kondisi perkembangan peserta didik.

Adapun menurut Kamal (2006, p. 48:53), hasil belajar yang dicapai oleh peserta didik dipengaruhi oleh faktor-faktor berikut ini :

Pertama, tujuan. Tujuan adalah pedoman, sekaligus sebagai sasaran yang akan dicapai dalam kegiatan belajar mengajar. Tercapainya tujuan berarti keberhasilan dalam pengajaran, karena itulah perumusan tujuan akan mempengaruhi kegiatan pengajaran yang dilakukan oleh guru dan secara langsung guru mempengaruhi kegiatan belajar peserta didik. Akan tetapi, jika kegiatan belajar peserta didik dan kegiatan mengajar guru bertentangan, dengan sendirinya tujuan pengajaran akan gagal dicapai.

Kedua, guru. Pandangan guru terhadap peserta didik akan mempengaruhi kegiatan belajar mengajar di kelas. Guru memandang peserta didik sebagai makhluk individual dengan segala perbedaannya, akan berbeda dengan guru yang memandang peserta didik sebagai makhluk sosial.

Ketiga, peserta didik. Keberhasilan peserta didik yang beraneka ragam mempengaruhi kegiatan belajar mengajar berikut hasil dari kegiatan itu sendiri, yaitu keberhasilan belajar mengajar.

Keempat, kegiatan pengajaran. Pola umum kegiatan pengajaran adalah terjadinya interaksi antara guru dan peserta didik dengan bahan sebagai perantaranya. Strategi penggunaan metode mengajar amat menentukan 
kualitas hasil belajar mengajar. Bermacam-macam penggunaan strategi mengajar akan menghasilkan hasil belajar mengajar yang berlainan kualitasnya.

Kelima, bahan dan alat evaluasi. Bahan evaluasi adalah suatu bahan yang terdapat dalam kurikulum yang sudah dipelajari oleh peserta didik untuk kepentingan ulangan. Masing-masing alat evaluasi tersebut mempunyai kelebihan dan kekurangan, maka dalam prakteknya sering merupakan penggabungan lebih dari satu alat evaluasi.

Keenam, suasana evaluasi. Pelaksanaan evaluasi biasanya dilaksanakan di dalam kelas dengan melibatkan seluruh peserta didik dengan dipantau oleh para pengawas. Selama pelaksanaan evaluasi, selama itu pula pengawas mengamati semua sikap, gerak gerik yang dilakukan oleh peserta didik. Namun dalam kenyataannya sikap pengawas berbeda-beda, ada yang ketat dan ada yang longgar, dan sikap anak pun berbeda-beda juga, ada yang jujur dan ada yang tidak jujur, sehingga ada yang berani mencontek atau meminta bantuan kepada teman-temannya.

Dari uraian di atas, dapat disimpulkan bahwa ada banyak faktor yang mempengaruhi hasil belajar, secara garis besar faktor-faktor tersebut adalah faktor internal (bersumber dari dalam diri) seperti sikap, minat, bakat, motivasi, kesiapan mental dan faktor lainnya yang kesemuanya berasal dari dalam diri sendiri. Adapun selanjutnya yaitu faktor eksternal (bersumber dari luar diri) seperti tempat belajar, sarana belajar, bahan pelajaran, personil, kurikulum, metode pembelajaran dan sebagainya.

Penilaian dalam proses pembelajaran meliputi: 1) Evaluasi formatif adalah penilaian yang dilakukan guru setelah satu pokok bahasan selesai dipelajari oleh peserta didik. Penilaian formatif disebutkan dengan istilah penilaian pada akhir satu pelajaran. Penilaian ini berfungsi untuk mengetahui sejauh mana ketercapaian tujuan intruksional khusus yang telah ditentukan dalam standar kompetensi; 2) Evaluasi sumatif adalah penilaian yang diselenggarakan oleh guru setelah satu jangka waktu tertentu. Penilaian sumatif berguna untuk memperoleh informasi tentang keberhasilan belajar peserta didik yang dipakai sebagai masukan utama untuk menentukan nilai lapor atau nilai akhir semester; 3) Pelaporan hasil penilaian, yaitu setelah memberikan evaluasi formatif dan sumatif, setiap tengah semester atau akhir semester guru harus memasukan ke dalam buku lapor yang merupakan laporan hasil kerja; 4) Pelaksanaan program perbaikan dan pengayaan, yaitu apabila seorang peserta didik dalam ulangan (tes formatif atau tes sumatif) mencapai nilai kurang dari 6,00 atau daya upaya serapnya kurang dari 60\% maka yang bersangkutan harus melakukan perbaikan. Tujuan ulangan perbaikan adalah agar peserta didik memperoleh penguasaan yang baik terhadap tujuan pembelajaran yang harus dicapai, dengan memberikan tugas tambahan kepada peserta didik yaitu 
mengerjakan kembali soal. Bagi peserta didik yang sudah mencapai standar kompetensi, sekurang-kurangnya $60 \%$ dapat diberikan pengayaan, apabila masih ada waktu untuk satu pelajaran tertentu sebelum beralih kepada materi lain (Suryobroto, 2002, p. 53).

\section{Metode Penelitian}

Penelitian ini menggunakan metode Penelitian Tindakan Kelas (PTK) model Kurt Lewin. Teknik pengumpulan data yang digunakan adalah observasi dan tes. Penelitian ini bertujuan untuk meningkatkan hasil belajar peserta didik pada mata pelajaran PAI. Penelitian ini bertujuan untuk meningkatkan hasil belajar peserta didik pada mata pelajaran PAI. Penelitian Tindakan Kelas di kelas VIII H SMP Negeri 1 Baregbeg Kabupaten Ciamis.

\section{Hasil Penelitian dan Pembahasan}

Penelitian tindakan kelas ini dilaksanakan sebanyak 3 siklus, satu siklus dilaksanakan satu kali pertemuan. Penelitian ini telah dilaksanakan di SMP Negeri 1 Baregbeg Kabupaten Ciamis tahun pelajaran 2018/2019.

Penyusunan Rencana Pelaksanaan Pembelajaran (RPP) sudah meningkat, berdasarkan penilaian yang dilakukan observer penyusunan RPP dari siklus ke siklus mengalami peningkatan. Akan tetapi, tidak dapat dipungkiri bahwa dalam setiap siklusnya terdapat beberapa kekurangan yang menjadi catatan bagi peneliti. Pada siklus I yaitu mengenai ketepatan ejaan, penggunaan bahasa, perumusan indikator dan tujuan pembelajaran, siklus II masih mengenai aspek ketepatan ejaan dan perumusan materi pokok, dan siklus III semua aspek harus ditingkatkan lagi. Berdasarkan data dari hasil observasi, nilai rata-rata pada setiap siklus, yaitu siklus I mencapai 81,54 siklus II mencapai 85,27 dan siklus III mencapai 88,09.

Kinerja guru dalam melaksanakan proses pembelajaran juga mengalami peningkatan. Dari tiga siklus yang telah dilaksanakan dalam penelitian tindakan kelas ini, pelaksanaan proses pembelajaran semakin baik. Akan tetapi, tidak dapat dipungkiri bahwa dalam setiap siklusnya terdapat beberapa kekurangan yang menjadi catatan bagi peneliti. Pada siklus I yaitu mengenai aspek apersepsi, intonasi suara, cara membangkitkan perhatian peserta didik dan hubungan emosional dengan peserta didik, siklus II masih mengenai intonasi suara dan hubungan emosional dengan peserta didik, dan siklus III semua aspek harus ditingkatkan lagi. Berdasarkan penilaian observer, pada pembelajaran siklus I nilai rata-ratanya mencapai 83,71 siklus II mencapai 87 dan siklus III mencapai 90,28. 
Hasil belajar peserta didik pada pembelajaran PAI dengan menerapkan metode Giving Question and Getting Answer juga mengalami peningkatan. Berdasarkan penelitian tindakan kelas yang telah dilakukan hasilnya semakin meningkat. Karena kekurangan-kekurangan yang terjadi dari siklus I sampai siklus III dapat peneliti atasi dengan baik. Seperti dalam kegiatan proses pembelajaran, peneliti mengkombinasikan metode Giving Question and Getting Answer dengan metode permainan agar siswa tidak merasa bosan, selain itu juga melakukan ice breaking untuk menambah semangat belajar peserta didik. Hal itu dapat dilihat dari hasil tes akhir bahwa dari seluruh peserta didik menunjukkan nilai tertinggi 100 dan nilai terendah 60 . Hasil belajar peserta didik dapa siklus I mendapat nilai rata-rata 75,29 pada perhitungan 24 orang sudah tuntas dan 10 orang yang belum tuntas dari nilai KKM yang telah ditentukan, siklus II dengan nilai rata-rata 78,94 pada perhitungan 28 orang sudah tuntas dan 6 orang yang belum tuntas dari nilai KKM yang ditentukan, siklus III dengan nilai rata-rata 84,85 pada perhitungan 31 orang sudah tuntas dan 3 orang belum tuntas dari nilai KKM yang ditentukan.

Penelitian ini berhasil membuktikan dugaan bahwa metode giving question dan getting answar dapat membantu meningkatkan hasil belajar. Berkaitan dengan hasil belajar, ditemukan di lapangan bahwa hasil belajar PAI di SMP Negeri 1 Baregbeg masih ada yang belum tuntas bila berstandar pada KKM yang ditetapkan sekolah sebesar 72. Berdasarkan hasil observasi dan wawancara dengan guru PAI di SMP Negeri 1 Baregbeg pada 10 April 2018 ditemukan dari jumlah peserta didik kelas VIII $\mathrm{H}$ yang berjumlah 34 peserta didik, yang mencapai ketuntasan belajar sebanyak 17 atau 50\% dan peserta didik yang belum mencapai ketuntasan sebanyak 17 atau 50\%. Hasil ini menunjukkan bahwa ketuntasan belajar peserta didik belum mencapai target sebagaimana yang telah ditetapkan yaitu 72 .

Rendahnya hasil belajar peserta didik disebabkan karena penerapan metode yang belum dilaksanakan secara maksimal, ini dapat dilihat dalam praktiknya peserta didik diperintahkan mencatat materi dan mendengarkan penjelasan guru sampai jam pelajaran selesai, sehingga belum dapat mengaktifkan peserta didik secara penuh dalam proses belajar mengajar.

Cara belajar seperti ini dapat menyebabkan peserta didik cepat jenuh, bosan, dan kurang semangat dalam mengikuti pembelajaran, kemudian menyebabkan pembelajaran PAI menjadi kurang menarik. Sebagai konsekuensi logis dari kondisi tersebut adalah bila tidak diupayakan perbaikan mutu proses pembelajaran dengan perbaikan metode pembelajaran tentu hasil belajar peserta didik pada mata pelajaran PAI menjadi tidak baik.

Berdasarkan masalah di atas perlu kiranya diperkenalkan sebuah metode pembelajaran yang lebih menitikberatkan keaktifan dan berorientasi pada 
peserta didik. Salah satu metode pembelajaran yang lebih banyak melibatkan keikutsertaan peserta didik dalam proses belajar adalah metode pembelajaran Giving Question and Getting Answer. Hal ini sesuai dengan pandangan Suprijono (2012, p. 107) mengemukakan bahwa Giving Question and Getting Answer ditemukan oleh Spancer Kagan, orang berkebangsaan Swiss pada tahun 1963 merupakan metode pembelajaran yang dapat merangsang, memancing serta mengajak peserta didik untuk ikut berpartisipasi aktif. Metode pembelajaran ini dikembangkan untuk melatih peserta didik memiliki kemampuan dan keterampilan bertanya dan menjawab pertanyaan. Metode ini juga dapat digunakan sebagai tolak ukur untuk menetapkan kadar pengetahuan setiap peserta didik dalam suatu kelas. Juga pandangan Hamruni (2011, p. 171) mengemukakan bahwa Giving Question and Getting Answer adalah strategi atau metode pembelajaran yang diarahkan untuk melibatkan peserta didik dalam meninjau ulang materi pelajaran dari pelajaran sebelumnya atau di akhir pertemuan. Adapun menurut Suprijono (2012, p. 107), Giving Question and Getting Answer adalah metode pembelajaran yang dikembangkan untuk melatih peserta didik memiliki kemampuan dan keterampilan bertanya dan menjawab pertanyaan.

Nasih \& Nurkolidah (2009, p. 54) mengemukakan bahwa secara umum tanya jawab ini berguna untuk mencapai banyak tujuan, antara lain: 1) Memotivasi peserta didik untuk berbuat dan menunjukkan kebenaran serta membangkitkan semangat untuk maju; 2) Mengetahui penguasaan peserta didik terhadap pengetahuan yang telah lalu agar guru dapat menghubungkannya dengan topik bahasan yang baru atau memeriksa efektivitas pengajaran yang dijalaninya; 3) Menguatkan pengetahuan dan gagasan pada pelajaran dengan memberi kesempatan untuk mengajukan persoalan yang belum dipahami dan guru mengulang bahan pelajaran yang berkaitan dengan persoalan tersebut. Sementara itu Suprijono (2012, p. 20) mengemukakan bahwa ada beberapa kelebihan metode Giving Question and Getting Answer yaitu: 1) Suasana pembelajaran menjadi aktif, karena dengan menerapkan metode Giving Question and Getting Answer dalam pembelajaran, peserta didik akan menjadi aktif, artinya mereka akan banyak terlibat selama proses pembelajaran berlangsung; 2) Peserta didik mendapat kesempatan baik secara individu maupun kelompok untuk menanyakan hal-hal yang belum dimengerti menyangkut materi yang telah disampaikan; 3) Guru dapat mengetahui penguasaan peserta didik terhadap materi yang telah disampaikan. Hal tersebut dapat diketahui dari kemampuan peserta didik dalam menjawab pertanyaan yang disampaikan oleh temanya ataupun guru, dan kemampuan peserta didik dalam mengungkapkan gagasan-gagasan yang ia sampaikan ketika proses pembelajaran berlangsung; 4) Mendorong peserta didik untuk berani 
mengajukan pendapatnya, karena untuk menumbuhkan keberanian bertanya bagi peserta didik itu tidak mudah, kebanyakan peserta didik itu malu untuk bertanya. Tetapi dengan menerapkan metode ini, peserta didik dapat terdorong hatinya untuk mengajukan pertanyaan. Suprijono (2012, p. 21) mengemukakan bahwa ada beberapa kekurangan metode Giving Question and Getting Answer yaitu: 1) Pertanyaan yang disampaikan oleh peserta didik itu hanya hafalan saja, artinya pertanyaan yang telah disampaikan bisa saja terlupakan atau mungkin sengaja untuk dilupakan; 2) Proses tanya jawab yang berlangsung secara terus menerus akan menyimpang dari pokok bahasan yang sedang dipelajari. Pertanyaan yang disampaikan oleh peserta didik itu dan bahkan jawaban yang diberikan itu bisa saja keluar dari materi yang diajarkan jika pertanyaan terlalu banyak; 3) Guru tidak mengetahui secara pasti apakah anak yang tidak mengajukan pertanyaan ataupun menjawab telah memahami dan menguasai materi yang telah diberikan atau tidak. Suprijono (2009, p. 107:108) menyebutkan langkah-langkah metode pembelajaran Giving Question and Getting Answer sebagai berikut: 1) Bagikan dua potong kertas kepada peserta didik; 2) Mintalah kepada peserta didik menuliskan kartu itu (1) kartu menjawab (2) kartu bertanya; 3) Pertanyaan bisa berasal dari peserta didik maupun guru. Jika pertanyaan berasal dari peserta didik, maka peserta didik diminta menyerahkan kartu bertuliskan kartu bertanya; 4) Setelah pertanyaan diajukan, mintalah kepada peserta didik memberi jawaban. Setiap peserta didik yang hendak menjawab diwajibkan menyerahkan kartu yang bertuliskan kartu menjawab. Perlu diingat, setiap peserta didik yang hendak menjawab maupun bertanya harus menyerahkan kartu itu kepada guru.

\section{Kesimpulan}

Berdasarkan hasil penelitian tindakan kelas yang dilakukan peneliti pada pembelajaran PAI dengan menerapkan metode Giving Question and Getting Answer yang dilaksanakan di kelas VIII H SMP Negeri 1 Baregbeg Kabupaten Ciamis, maka peneliti menyimpulkan hal-hal sebagai berikut. Pertama, penyusunan perencanaan pembelajaran PAI di kelas VIII H SMP Negeri 1 Baregbeg Kabupaten Ciamis dengan menerapkan metode pembelajaran Giving Question and Getting Answer mengalami peningkatan. Hal ini dapat dilihat dari hasil observasi pada siklus I mencapai nilai rata-rata 81,54 , siklus II mencapai nilai 85,27 dan siklus III mencapai nilai 88,09. Kedua, pelaksanaan proses pembelajaran pada mata pelajaran PAI di kelas VIII H SMP Negeri 1 Baregbeg Kabupaten Ciamis dengan menerapkan metode Giving Question and Getting Answer mengalami peningkatan. Hal ini dapat dilihat berdasarkan penilaian observer pada pembelajaran siklus I dengan nilai rata-rata mencapai 83,71, 
siklus II mencapai 87 dan siklus III mencapai 90,28. Ketiga, Hasil belajar peserta didik kelas VIII H SMP Negeri 1 Baregbeg Kabupaten Ciamis setelah mengukuti pembelajaran PAI dengan menerapkan metode pembelajaran Giving Question and Getting Answer mengalami peningkatan. Hal ini dapat dilihat dari hasil siklus I mendapat nilai rata-rata 75,29, siklus II dengan nilai rata-rata 78,94, dan siklus III dengan nilai rata-rata 84,85.

\section{DAFTAR PUSTAKA}

Abdullah, S. (2012). Evaluasi Pembelajaran Konsep Dasar, Teori dan Aplikasi. Semarang: Pustaka Rizki Putra.

Achmadi. (2005). Ideologi Pendidikan Islam Paradigma Humanisme Teosentris. Yogyakarta: Pustaka Pelajar.

Ali, M. (2002). Guru dalam Proses Belajar Mengajar. Bandung: Sinar Baru Algesindo.

Arif, A. (2008). Pengantar Ilmu Pendidikan Islam. Jakarta: Kultura.

Azizi, Q. (2003). Pendidikan untuk Membangun Etika Sosial (Mendidik Anak Sukses Masa Depan; Pandai dan Bermanfaat). Semarang: Aneka Ilmu.

Baharudin, \& Wahyuni. (2015). Teori Belajar dan Pembelajaran. Jakarta: ArRuzz Media.

Daradjat, Z. (1996). Ilmu Pendidikan Islam. Jakarta: Bumi Aksara.

Daryanto. (2007). Evaluasi Pendidikan. Jakarta: Rineka Cipta.

Dimayati, \& Mudjiono. (2006). Belajar dan Pembelajaran. Jakarta: Rineka Cipta.

Djamarah, S. B., \& Zain, A. (2006). Strategi belajar mengajar. Jakarta: Rineka Cipta.

Hamalik, O. (2008). Proses Belajar Mengajar. Jakarta: Bumi Aksara.

Hamruni. (2011). Strategi Pembelajaran. Yogyakarta: Insan Madani.

Kamal, M. (2006). Buku Ajar Strategi Mengajar untuk Fakultas Tarbiyah. Ciamis: IAID Ciamis.

Kurdi, S. (2006). Model Pembelajaran Efektif Pendidikan Agama Islam di SD dan MI. Bandung: Pustaka Bani Quraisy.

Majid, A., \& Andayani, D. (2004). Pendidikan Agama Islam Berbasis Kompetensi. Bandung: Remaja Rosydakarya.

Muhaimin. (2006). Nuansa Baru Pendidikan Islam: Mengurai Benang Kusut Dunia Pendidikan. Jakarta: PT Raja Grafindo Persada.

Nafis, M. M. (2011). Ilmu Pendidikan Islam. Yogyakarta: Teras.

Nasih, A. M., \& Nurkolidah, L. (2009). Metode dan Teknik Pembelajaran Agama Islam. Bandung: Refika Aditama.

Ramayulis. (2005). Metodologi Pendidikan Agama Islam. Jakarta: Kalam Mulia. 
Sopiatin, P., \& Sahroni, S. (2011). Psikologi Belajar dalam Perspektif Islam. Bogor: Ghalia Indonesia.

Sudjana, N. (2010). Dasar-Dasar Proses Belajar Mengajar. Bandung: Sinar Baru Algesindo.

Sudjana, N. (2011). Penilaian Hasil Proses Belajar. Bandung: Sinar Baru Algesindo.

Sulhan, N., \& et.al. (2012). Panduan Mengajar Akidah Akblak Madrasah Ibtidaiyah. Jakarta: Zikrul Hakim.

Suprijono, A. (2009). Cooperative Learning, Teori dan Aplikasi Paikem. Yogyakarta: Pustaka Pelajar.

Suprijono, A. (2012). Cooperative Learning, Teori dan Aplikasi Paikem. Yogyakarta: Pustaka Pelajar.

Suryobroto, A. (2002). Penilaian Belajar Mengajar di Sekolah. Jakarta: Rineka Cipta.

Wahidmurni. (2010). Evaluasi Pembelajaran. Yogyakarta: Nuha Litera.

Winkel. (1996). Psikologi Pengajaran. Yogyakarta: Media Abadi.

Zuhairini. (1993). Metodologi Pendidikan Agama. Solo: Ramadhani.

Zulkarnain. (2008). Transfromasi Nilai-nilai Pendidikan Islam: Manajemen Berorientasi Link dan Match. Yogyakarta: Pustaka Pelajar. 
